\title{
PRINCÍPIO DA DESCENTRALIZAÇĀO ADMINISTRATIVA ATRAVÉS DA CRIAÇÃO DE EMPRESAS ESTATAIS *
}

\author{
Marcos Juruena Villela Souto \\ Mestrando em Direito das Relações Econômicas da Universidade Gama Filho \\ Procurador do Estado do Rio de Janeiro \\ Advogado
}

Resumo:

O artigo examina o princípio da descentralização através da criação de empresas estatais e a possibilidade de os estados e municípios virem a instituí-las.

Trata a seguir das principais teorias acerca da origem e das funções do Estado, especialmente no que toca à função de administrar. Aborda a estrutura da administração, direta e indireta, as definições do DL n. 200/67, no seu artigo $5^{\circ}$, o princípio da descentralização e suas formas, a descentralização por desconcentração ou por colaboração, a descentralização através das empresas estatais.

Analisa os tipos de empresas estatais, a vacilação da doutrina no que concerne à existência de dois tipos de empresa estatal, exploradora de atividade econômica e prestadora de serviços públicos e os pareceres dos juristas acerca do tema. Finaliza com as empresas estatais de estados e municípios e a privatização como correção dos abusos da descentralização.

Abstract:

The article examines the principle of decentralization through the creation of state companies and the possibility of they being instituted by states and municipalities.

After that it goes into the main theories about the origin and functions of the state, specially the aspect of its administrative function. It looks into the structure of administration, direct and indirect, the definitions of the Executive Law n. 200/67, in the 5th. section, the principle of decentralization and its forms, decentralization through cooperation, decentralization through state companies.

It analyses the types of state companies, the hesitation of doctrine concerning the existence of two types of state companies, exploiter of the economic activity and renderer of public services and the opinion of jurists on the theme. It ends with the state companies of states and

* Rio de Janeiro, 26 de novembro de 1992. 
municipalities and the privatization as a corrector of the abuses of decentralization.

Sumário:

1. Objetivo e método.

2. Origem do poder e do Estado.

3. A função de administrar.

4. Estrutura da Administração.

5. O princípio da descentralização e suas formas.

6. A descentralização através de empresas estatais.

7. Tipos de empresas estatais.

8. Empresas estatais de Estados e Municípios.

9. A privatização como correção dos abusos na descentralização.

\section{Objetivo e método.}

O objetivo do presente estudo é examinar o princípio da descentralização através da criação de empresas estatais e a possibilidade de os Estados e Municípios virem a instituí-las. Para tanto, vai se analisar a origem e as funções do Estado e, especificamente dentro da função de administrar, a forma de seu desempenho. Nesse passo, vai se enfocar a estrutura centralizada e descentralizada da Administração e o princípio da descentralização, como orientação; dentre as formas da descentralização, a criação de empresas estatais, nas suas duas formas sociedade de economia mista e empresa pública e o respectivo amparo constitucional, para, por fim, responder à indagação proposta e soluções para o problema de indevida descentralização.

\section{Origem do poder e do Estado. ${ }^{1}$}

Santo Tomás de Aquino, um dos mais notáveis seguidores de Aristóteles, afirmava, a exemplo de seu mestre, que "o homem é, por natureza, animal social e político", sendo, pois, no dizer de Ranelletti, uma necessidade

1. Dalmo de Abreu Dallari, Elementos de Teoria Geral do Estado, 14a ed., Sāo Paulo, Saraiva, 1989. 
natural a vida em sociedade, através da qual pode ele, com a convivência e cooperação dos semelhantes, atingir os fins de sua existência.

Platão, e mais tarde Hobbes, por outro lado, entendiam que algo além dessa natural tendência era necessária para que o homem vivesse em sociedade, que vinha a ser o elemento vontade. Partiu-se, daí, para uma noção contratualista, segundo a qual a base da vida social, como evolução do estado natural, estaria em duas leis: a primeira, obrigando os homens a lutar pela paz; a segunda, a renúncia individual ao direito sobre todas as coisas em prol do respeito geral à sua própria liberdade. Era a idéia de um "contrato social", sustentada por Rousseau, através do qual há mútua transferência de direitos em prol do bem-estar geral.

Titularizando cada ser humano um poder, isto é, a faculdade de transformar vontade em atos, aos poucos, o homem foi sentindo a necessidade, decorrente da vida social num determinado território, de transferir o seu exercício (e não a titularidade) a um representante, para que este, agindo em nome da vontade de todos, zelasse pelo bom funcionamento da sociedade. Surgiu, então, a noção de Estado.

A soberania, inserida na pessoa do governante, previa a tarefa de administrar a vida social, resolver, até mesmo pela força, os conflitos, de acordo com normas por ele mesmo elaboradas. Foi Aristóteles quem, primeiramente, identificou essas três funções do Estado, cuja atuação deveria pautar-se pela consecução do bem comum, de acordo com os anseios da sociedade que lhe transfere o exercício desse poder.

O ordenamento jurídico, como evolução do ordenamento social, surge, então, como forma de disciplina das ações na vida social de acordo com os objetivos por ela (sociedade) traçados. A norma jurídica é mera positivação conseqüente desse ordenamento. A noçāo de ordem jurídica é, pois, mais ampla que a de norma jurídica.

Observa Dalmo de Abreu Dallari que "cada indivíduo, cada grupo humano e a própria sociedade, no seu todo, devem sempre ter em conta as exigências e as possibilidades da realidade social, para que as ações não se desenvolvam em sentido diferente daquela que conduz efetivamente ao bem comum". 
Contudo, o fortalecimento da figura do governante na derrocada da Idade Média, levando ao absolutismo, fez com que o exercício do poder fugisse aos anseios da sociedade que dele era titular. Aliás, num superficial exame histórico, é fácil detectar que o exercício do poder fatalmente leva ao abuso.

Foi Montesquieu quem, sistematizando a lição de Aristóteles, preconizou que o exercício das três funções básicas do Estado deveria caber a pessoas diferentes.

A retomada do poder pelo povo que o titularizava, na célebre Revolução Francesa de 1789, foi o grande marco da história da vida em sociedade fazendo valer a teoria da tripartição das funções do Estado idealizada por Montesquieu. Deu-se a primeira descentralização.

O poder, emanado do povo e em seu nome exercido, continuava único, apenas o seu exercício fracionado, como forma de manutenção da harmonia e do equilíbrio da vida em sociedade, cabendo a cada órgão o exercício de uma função primordial (administrar, legislar, julgar), sabendo que agia dentro de limites controlados pelos demais órgãos.

O advento do Estado Constitucional procurou afirmar a supremacia do indivíduo, a necessidade de limitação do poder e a busca do seu exercício de forma racional.

No Brasil, com a retomada do Estado de Direito, um Estado limitado pela ordem jurídica, a Constituição de 1988 manteve a essência do legado da Revolução Francesa de 1789, preconizando o exercício independente, porém harmônico, dos poderes estatais (art. $2^{o}$ ), deixando expresso que tais poderes pertencem ao indivíduo e em seu nome deve ser exercido, por ele ou por meio de representantes (art. $1^{\mathfrak{Q}}, \S$ único). Além da repartição funcional do poder, o Estado Federal contempla, ainda, a divisão espacial do poder, entre União, Estados, Municípios e Distrito Federal, cada qual com autonomia política, administrativa e legislativa, nos termos das competências que lhes for atribuída pela Lei Maior.

\section{A função de administrar.}

Mais do que criar e estruturar o Estado brasileiro, matéria tipicamente constitucional, o constituinte de 1988 teve o cuidado de neutralizar 
um pouco a hipertrofia do administrador no regime presidencialista, traçandolhe princípios de atuação: a legalidade, a publicidade, a impessoalidade e a moralidade, que, em suma, dizem o seguinte:

legalidade a Administração só pode agir de acordo com os mandamentos de lei;

moralidade - agir de acordo com a ética (honestidade);

impessoalidade $\mathrm{o}$ ato deve atender o interesse geral e não o pessoal (seja do administrador, seja do administrado);

publicidade os atos da Administração devem ser públicos e divulgados (só são sigilosos os casos que afetem a segurança nacional).

Portanto, administrar seria a função do Estado não englobada na função de legislar - traçar comandos genéricos para a convivência social, prevenindo conflitos de interesses e de julgar solucionar concreta e definitivamente esses conflitos. Diogo de Figueiredo Moreira Neto em seu Curso de direito administrativo classifica as atividades administrativas em cinco ordens, a saber: interesse coletivo;

- poder de polícia limitação de atividades individuais em prol do serviços públicos atendimento de necessidades sociais (ex: transportes, água, luz);

ordenamento econômico - disciplina (e até substitui) as atividades de produção, circulação e consumo das riquezas;

ordenamento social disciplina o desenvolvimento social com sentido de amparo ao homem (ex: direito do trabalho e direito previdenciário);

- fomento público colocação de instrumentos para o desenvolvimento econômico e progresso sócio-cultural (ex: incentivos fiscais, subsídios, financiamentos).

É claro que muitas dessas funções, por força do citado princípio da legalidade, serão exercidas em parceria com o Poder Legislativo, que aprovará as leis necessárias para legitimação dos atos administrativos. 


\section{Estrutura da Administração.}

Para desempenho de suas funções, a Administração pode funcionar de forma centralizada, isto é, o poder será exercido diretamente pelo ente político criado pela Constituição Federal, ou por criaturas decorrentes de seu poder de auto-organização, por execução direta ou em colaboração com terceiros. É o que se chama descentralização.

Descentralização é, na lição sempre atualizada de Hely Lopes Meirelles - in Direito administrativo brasileiro -, afastar do centro; "em sentido jurídico-administrativo, é atribuir a outrem poderes de Administração", cujo titular é o Estado.

Daí a estrutura da Administração Pública em administração centralizada, chamada administração direta entidades políticas criadas pela Constituição, e administração descentralizada, englobando aí a administração indireta - autarquias, sociedades de economia mista e empresas públicas (que exercem atribuições inerentes ao Estado) e a administração fundacional que compreende as fundações de direito privado instituídas pelo Poder Público.

Entendemos que a opção de exercer as funções de administração do Estado de forma centralizada e descentralizada constitui um poder discricionário do administrador, isto é, do Chefe do Poder Executivo, atualmente (em face dos abusos do passado) submetido ao controle do Poder Legislativo. Diz o art. 37, XIX, da Constituição Federal, que "somente por lei especifica poderāo ser criadas empresa pública, sociedade de economia mista, autarquia ou fundação pública"; ainda para controlar eventuais distorções dessas criaturas, esclarece o inciso $\mathrm{XX}$ do mesmo dispositivo que "depende de autorizaçāo legislativa, em cada caso, a criação de subsidiárias das entidades mencionadas no inciso anterior, assim como a participaçāo de qualquer delas em empresa privada". É o caso, também, das controladas, que, mesmo não integrando a administração indireta ou fundacional, recebem, direta ou indiretamente, recursos públicos.

Em que pesem os abusos que ocorreram no passado (onde, pela via da descentralização para estatais, se contratava pessoal sem concurso público, bens e serviços sem licitação e dívida externa sem a aprovação do Senado Federal), não existe uma lei que defina quando e por que forma descentralizada. Como dito, a matéria insere-se no poder discricionário do administrador, 
cabendo ao legislador o controle casuístico de cada ato. Foi a fórmula que o constituinte encontrou de solucionar esses abusos sem violar a doutrina do Direito Administrativo. A lei decorrente da descentralização é ato formalmente legislativo mas materialmente administrativo.

Existem, a nível federal, as definições do Decreto-lei n. 200/67, constantes de seu art. $5^{\circ}$, in verbis:

"I - autarquia o serviço autônomo, criado por lei, com personalidade jurídica, patrimônio e receita próprios, para executar atividades típicas da Administração Pública, que requeiram, para seu melhor funcionamento, gestāo administrativa e financeira descentralizada;

II empresa pública a entidade dotada de personalidade jurídica de direito privado, com patrimônio próprio e capital exclusivo da União, criada por lei para a exploraçâo de atividade econômica que o Governo seja levado a exercer por força de contingência ou de conveniência administrativa, podendo revestir-se de qualquer das formas admitidas em direito;

III sociedade de economia mista - a entidade dotada de personalidade jurídica de direito privado, criada por lei para a exploração de atividade econômica, sob forma de sociedade anônima, cujas ações de direito a voto pertençam, em sua maioria, à União ou à entidade da Administraçāo Indireta".

Os conceitos são federais, muito embora sejam repetidos nas demais esferas de governo.

Não se falou em fundações. As dúvidas sobre a inserção das fundações no âmbito da administração indireta ou fora da estrutura da Administração Pública levaram a dúvidas quanto ao seu conceito e natureza jurídica, se de direito público ou privado.

A solução para esse impasse está intimamente ligada à definição do objeto da entidade. Aspectos como a criação por lei, o recebimento de verbas 
públicas, o ingresso por concurso nos seus quadros, a fiscalização do Tribunal de Contas, etc. não são suficientes para enquadrar a entidade como pública ou privada. É, primordialmente, o objetivo da entidade que the confere uma personalidade pública ou privada. Daí concluir-se que tanto podem existir "fundações de direito público" ou "fundações públicas", como têm sido chamadas como "fundações de direito privado instituídas pelo Poder Público"

É o que ensina, com clareza solar, o ilustre procurador do Estado de São Paulo Edmir Netto de Araújo (Revista de Direito da Procuradoria Geral do Estado de São Paulo, v. 32, 1989, p. 179-192), in verbis:

"... Nessa manifestação, afirmávamos que a categoria jurídica fundação, descompromissada com qualquer dos ramos (público ou privado) em que se divide o direito, significa 'patrimônio personalizado $e$ dirigido a um fim'. $O$ item 'patrimônio', todavia, poderá estar afetado a um fim público ou privado, embora no segundo caso possa trazer conotações de interesse público ou social (fins assistenciais, filantrópicos, culturais), e esses dados determinam a finalidade de fundação"

Assim, até uma adequada disciplina do tema, ter-se-ão fundações públicas, submetidas ao mesmo regime das autarquias (daí serem chamadas de "fundações autárquicas" ou "autarquias fundacionais") e fundações de direito privado instituídas e/ou. mantidas pelo Poder Público. As primeiras integram a administração indireta (como autarquias), estas, a chamada administração fundacional.

Para equacionar o tema para o futuro e moralizar a criação de tais entidades -, a Constituição do Estado do Rio de Janeiro, em seu art. 77, § 2², IV, considera fundação pública "a entidade de personalidade jurídica de direito privado, sem fins lucrativos, criada em virtude de autorização legislativa, para o desenvolvimento de atividades que não exijam execução por órgãos ou entidades de direito público, com autonomia administrativa, patrimônio próprio gerido pelos respectivos órgãos de direçāo e funcionamento custeado por recursos do Estado e de outras fontes" 
Tal conceito, no entanto, vale da promulgação do ato em diante. Prossegue, portanto, a problemática do emprego indistinto da fundação pública até que haja uma casuística atividade legislativa corretiva.

\section{O princípio da descentralização e suas formas.}

Conforme supra-examinado, descentralização significa retirar do centro. Constitui, pois, uma opção técnico-administrativa de desmembramento do exercício do poder e não de sua titularidade, que, de qualquer modo, permanece com o povo, de quem emana em favor do Estado.

Desde a Revolução Francesa, a descentralização do poder estatal foi exercitada como forma de facilitar a fiel consecução dos objetivos do Estado. Foi a descentralização funcional nos Poderes Executivo, Legislativo e Judiciário (descentralização política).

Nos Estados Federais, como é o caso do Brasil, o poder estatal, além de funcionalmente dividido, também o é espacialmente dividido (divisão espacial do poder também política).

Daí incluir-se a descentralização dentre os princípios gerais de direito público, do qual o direito administrativo é um ramo.

No exercício do poder estatal de administrar, também devem ocorrer descentralizações, já que ao administrador cabe o desempenho de suas funções com eficiência (técnica, administrativa e financeira). Sendo um princípio, emana diretamente do ordenamento jurídico que dará substrato à norma jurídica; ainda que dela não conste expressamente, trata-se de um mandamento que decorre da própria existência de uma ordem jurídica. ${ }^{2}$

A nível federal, o Decreto-lei n. 200/67 o previu, expressamente, para a sua Administração Pública, no art. $6^{\circ}$, III e IV.

Vale esclarecer que não é apenas através da criação de autarquias ou de entidades paraestatais que ocorre a descentralização.

2. Diogo de Figueiredo Moreira Neto, em seu Curso de direito administrativo, $10^{\mathrm{a}}$ ed., Rio, Forense, 1992, p. 66, observa que tal descentralização também ocorre no Poder Legislativo, com a divisão do Congresso Nacional em duas Câmaras, e no Poder Juđiciário, através das leis de organização judiciária que criam Juízes de Direito Especializados e Câmaras nos Tribunais. 
Esta é a descentralização por outorga ou institucional, onde o Estado, através de lei, cria uma entidade (nova pessoa jurídica) e a ela transfere a titularidade de uma atividade administrativa. Assim, as autarquias e paraestatais passam a personalizar uma determinada junção.

A descentralização por desconcentração ocorre dentro da própria estrutura administrativa, sem criação de uma pessoa jurídica, objetivando o descongestionamento do serviço através da repartição das funções entre os órgãos. Decorre do poder hierárquico.

Faz-se, aqui, a distinção entre níveis de direção e execução, cabendo aos primeiros o planejamento e supervisão daquilo que vai ser executado. A divisão do Governo em ministérios e destes em repartições, agências, secretarias e diretorias é exemplo dessa técnica de especialização e liberação dos órgãos de cúpula. Evita-se, assim, que toda e qualquer atividade seja, imperativamente, examinada pela autoridade administrativa que se encontra no vértice da respectiva estrutura, reservando-lhe, assim, mais tempo para as decisões relevantes.

Por fim, tem-se a descentralização por delegação ou por colaboração, onde se transfere para terceiros, estranhos à estrutura da Administração Pública (direta, indireta ou fundacional), a execução transitória de atividades que a ela cabem. É que nem sempre (aliás, raras vezes), os órgãos e entidades que integram a Administração Pública são auto-suficientes para solucionar as demandas que decorrem do dinamismo do interesse público. Daí a necessidade de convidar a iniciativa privada a prestar a sua colaboração, o que ocorre através de atos administrativos, unilaterais (permissões), bilaterais (contratos) ou multilaterais (convênios).

Vale lembrar que, em decorrência do dever de eficiência, não basta que a Administração esteja apta a atender determinado interesse público; é indispensável que o faça de acordo com as melhores técnicas, ao menor preço e no momento oportuno. Aplicam-se integralmente à Administração Pública os conceitos de "terceirização" e de "just in time" utilizados pela administração privada.

Assume, então, primordial importância o procedimento de licitação, através do qual os órgãos e entidades da Administração Pública 
selecionam as propostas mais vantajosas (e não, as mais baratas) dentre as ofertas de particulares que com ela desejam colaborar.

Ao administrador público deve ser exigida a sensibilidade em captar aquilo em que ele pode ser mais eficiente que o particular, conciliando tal eficiência com as noções econômicas de custo de oportunidade e vantagem comparativa, descentralizando ou terceirizando (privatizando) certas atividades para dedicar-se às mais importantes ou de melhores resultados.

A escassez de recursos públicos, a necessidade de redução do tamanho do Estado e o imperioso dever de fomento às atividades da iniciativa privada (geradores de emprego e de receitas tributárias) tornam a terceirização da Administração Pública uma questão prioritária. O Estado deve reservar para si a política administrativa, transferindo, sempre que oportuno e conveniente, a execução administrativa aos particulares, a quem caberá o risco dos investimentos e o justo lucro o Estado não tem mais recursos para investir ou arriscar sem lançar mão de novos tributos, que levam o país à recessão; por outro lado, não tem o objetivo de auferir lucros; o que interessa é o atendimento do interesse público com a melhor técnica e ao menor custo. Daí o papel relevante das licitações e das contratações administrativas, hoje, sem dúvida, a melhor técnica de descentralização.

\section{A descentralização através das empresas estatais.}

$O$ presente estudo dedica-se a uma pequena parcela da descentralização, qual seja, a que se exerce através da criação de empresas estatais.

Para tanto, há necessidade de um breve histórico.

A descentralização administrativa surgiu, antes de mais nada, como um instrumento de libertação do Estado do formalismo que rege a ação administrativa. A adoção de formas de direito privado na gestão da entidade, na escrituração contábil, na celebração de contratos tornavam o Estado infinitamente mais ágil na consecução de seus fins.

Inicialmente, essa descentralização personalizava apenas os serviços públicos prestados pelo Estado. $\mathrm{O}$ exercício de atividades econômicas e, 
conseqüentemente, a produção de riquezas, competiam à iniciativa privada, sem que houvesse qualquer ingerência do Poder Público. Era o Estado liberal.

A primeira metade do século $\mathrm{XX}$ trouxe acontecimentos que desbancaram essa teoria de alheamento do Estado. Sucessivamente, a Primeira Guerra Mundial, a quebra da Bolsa de New York e a Segunda Guerra Mundial, todos com graves conseqüências, deixaram clara a necessidade de modificação nessa política, tornando imperiosa a presença do Estado, tanto na economia quanto na área social (obviamente não foi esse o momento do surgimento das empresas estatais, cujas origens remontam à época do mercantilismo séculos XVI e XVII -, através de empresas coloniais, inglesas e holandesas).

Surge o Estado intervencionista, legitimado a intervir na atividade privada, para condicionar o exercício dos direitos a determinados fins sociais. Não se tratava, pois, de um retorno ao absolutismo, cujos princípios não mais se adequavam em relação ao Estado de Direito.

Coube à Constituição alemã de Weimar, em 1919, desencadear esse processo de maior participação estatal na vida da sociedade. Como assinala A. B. Cotrim Neto, em seu trabalho denominado $A$ intervenção do Estado na economia - in Revista de Informação Legislativa no 96, p. 151 - "Pela primeira vez, quiçá, na história do pensamento jurídico, subordinava-se a economia a normas de direito público, e, sem dúvida pela primeira vez, inseriu-se o controle estatal da economia privada no quadro de uma Constituiçâo política (Constituição de Weimar, arts. 151, 17, 158, 164 e, especialmente, art. 165)".

No Brasil, a primeira Constituição a mencionar o tema foi a de 1934, determinando que a economia se organizasse de acordo com os princípios da justiça social e que possibilitasse vida digna, garantindo a liberdade econômica.

Com a Constituição de 1946 é que foram desenvolvidos os princípios dentro dos quais deveria se pautar a atividade econômica, conciliandose a livre iniciativa com a valorização do trabalho humano, assegurando o trabalho a todòs.

A Carta de 1967 enumerou cada um desses princípios, que deveriam destinar-se à realização da justiça social. A Emenda Constitucional de 1969 acrescentou, ainda, a finalidade de assegurar o desenvolvimento nacional. 
Com o advento da Constituição de 1988, o papel do Estado na economia foi remodelado. A ordem econômica funda-se na livre iniciativa e na valorização do trabalho humano, cabendo ao Estado as funções de fiscalização, incentivo e planejamento, sendo este determinante para o setor público e indicativo para o setor privado.

Assim, o papel do Estado na atividade econômica deixa de ser o de agente propulsor da economia e produtor da riqueza, função essa que é reservada à iniciativa privada; cabe-lhe reprimir os abusos e assegurar o bemestar da coletividade e o desenvolvimento do país.

Foram previstas quatro formas de intervenção: a normativa, a repressiva, a tributária e a exploração direta da atividade econômica.

Dá-se a intervenção normativa através da concessão da proteção e benefícios especiais e temporários a empresas brasileiras de capital nacional que desenvolvam atividades estratégicas para a defesa nacional ou imprescindíveis ao desenvolvimento do país. Por esse mecanismo, o Estado incentiva setores privados ao invés de ele próprio exercer tais atividades. Dá-se, ainda, a permissão do ingresso do capital estrangeiro no país, em hipóteses que a lei regulará.

A intervenção repressiva visa a coibir o abuso do poder econômico que tenha por finalidade a dominação de mercados, a eliminação da concorrência e o aumento arbitrário dos lucros. É a defesa do consumidor. Há, ainda, as polícias sanitária e ambiental.

A intervenção tributária caracteriza-se pela utilização do tributo como um meio de execução de uma política de seleção de fatos que denotam capacidade econômica contributiva ou para privilegiar alguns setores - ex: CF, art. 149.

Por fim, o que nos interessa, a intervenção através da exploração direta da atividade econômica, que ocorrerá sempre que for necessária aos imperativos de segurança nacional ou tenha por objetivo atender relevante interesse coletivo.

A própria Lei Maior já elenca setores que, devido à sua relevância, não admitem a participação da iniciativa privada, constituindo monopólio da União. São eles ligados ao petróleo, gás natural e aos minérios e minerais nucleares. 
Somente nessas hipóteses é que cabe ao Estado assumir a forma empresarial e ocupar um espaço que, na nova ordem constitucional, compete à iniciativa privada. Sujeita-se ele, então, a formas de direito privado, através da criação de empresas, e estas, via de conseqüência, ao regime jurídico de direito privado, quanto aos aspectos tributários e trabalhistas. Afinal, num Estado de Direito, não seria justo que o Poder Público, exercendo uma atividade concorrente com a do setor privado, se valesse de privilégios decorrentes de sua posição para obter melhores resultados.

A Carta Magna comete, ainda, ao Estado, o dever de prestação de serviços públicos, segundo a titularidade oriunda do sistema federativo de repartição de competências. Essa titularidade é inalienável. Pode o Estado, por lei, criar uma entidade que personalize esse serviço, titularizando-o, ou, então, delegar ao particular a sua execução. Esse aspecto assume importante papel ao se tratar de privatização de empresas estatais.

Por enquanto, é de fundamental importância que se frise que há dois tipos de empresas do Estado: as que se destinam à intervenção na atividade econômica e as que titularizam a prestação de serviços públicos.

$\mathrm{Na}$ organização da Administração Pública brasileira, estas empresas, muito embora integrem a chamada Administração indireta (ou melhor, Administração descentralizada, eis que destacadas da Administração centralizada ou direta), são pessoas jurídicas de direito privado e assumem duas formas básicas:

empresas públicas, quando forem constituídas com capitais eminentemente públicos;

sociedades de economia mista, quando o Estado se associa ao particular para a constituição do capital social. A forma é de sociedade anônima.

A competência para legislar em matéria empresarial, onde estão situadas as duas categorias supra, é privativa da União CF, art. 22, I (direito comercial).

O processo de criação dessas empresas no Brasil desencadeou-se durante a Segunda Guerra Mundial, quando razões de "segurança nacional" levaram à criação da Fábrica Nacional de Motores (cuja finalidade era a fabricação e manutenção de motores de avião), a Companhia Siderúrgica 
Nacional, a Companhia Vale do Rio Doce e a Companhia Hidrelétrica do São Francisco.

A década de 50 deu ensejo à criação da indústria de base, que mereceu o apoio financeiro do Governo com a criação do Banco Nacional de Desenvolvimento Econômico e Social. No mesmo período surgiu a Petrobrás.

Mas foi nas décadas de 60 e 70 que o Estado brasileiro empolgouse em dinamizar sua atividade empresarial, objetivando estar presente em áreas complementares às empresas de base originariamente criadas. Surgiram os grandes grupos da ELETROBRÁs, SIDERBRÁS, NUCLEBRÁS, PORTOBRÁS, TELEBRÁS. Consta que nesse período, segundo a SEST, mais de trezentas empresas estatais teriam sido criadas.

É óbvio que os diversos motivos que levaram ao excessivo intervencionismo estatal, em muitos casos, não mais estão presentes e não se coadunam com o texto constitucional vigente. Como visto, fora das hipóteses em que haja prestação de serviços públicos ou de exploração direta da atividade econômica para atender imperativos de segurança nacional ou relevante interesse coletivo não podem existir empresas estatais.

Urge, pois, que se corrija a anomalia do gigantismo do Estado, oriunda de uma política que lhe atribuiu o papel de conduto da economia. Este é o objetivo primordial da privatização: devolver à iniciativa privada um espaço que, em situação de normalidade, lhe compete, retornando o Estado às suas funções típicas, especialmente no que concerne ao essencial, como saúde pública, segurança, educação e saneamento. É a "privatização", objeto de um programa instituído pela Lei n. 8.031, de 12 de abril de 1990.

\section{Tipos de empresas estatais.}

Quer em razão da possibilidade e motivação para a criação, quer em face dos métodos de privatização, é indispensável analisar a finalidade a que se destina a empresa estatal.

A doutrina é vacilante no que concerne à existência de dois tipos de empresa estatal exploradora de atividade econômica (CF, art. 173, § 10), e empresa estatal prestadora de serviços públicos (CF, art. 175). 
O procurador do Estado do Rio de Janeiro e eminente administrativista Diogo de Figueiredo Moreira Neto, em "visto" ao Parecer n. 22, de 1991 - MTWM, da Procuradoria Geral do Estado do Rio de Janeiro, proferido no processo n. PRES.225/91 METRÔ, sustenta que:

"Com efeito, é preciso ter igualmente em linha de conta a distinção clássica e incontestada entre serviço público $e$ serviço de utilidade pública: o primeiro, pró-comunidade e o segundo, pró-cidadão, na tersa lição de Hely Lopes Meirelles, conformando esta, a 'atividade econômica que só poderá ser explorada pelo Poder Público' caracterizada pela 'produção de renda para quem os presta' (DAB, RT, SP, 14a ed., 1989, p. 290-291).

Se assim não fosse, as concessionárias privadas de serviço público perderiam também a sua condição empresarial.

E mais ainda. Nenhuma sociedade de economia mista poderia dedicar-se à exploração de atividade tida como serviço público, considerando que o Decreto-lei n. 200/67, com a redação que lhe foi dada pelo Decreto-lei $n$. 900/69, define-a como a entidade cujo objeto se encontra ligado à exploração de atividade econômica.

Observe-se, ademais, que a própria forma jurídica da sociedade anônima seria, no caso, de impossível adoção, uma vez que a Lei $n .6 .404 / 76$ (art. $2^{9}$ ) restringe o objeto da companhia a 'qualquer empresa de fim lucrativo'.

Deve-se, pois, assentar que a sociedade anônima, de economia mista ou não, e qualquer que seja o seu objeto, desenvolve sempre e necessariamente uma atividade econômica.

Conseqüentemente, o sadio principio constitucional

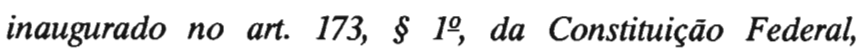
aplica-se a todas as sociedades de economia mista, as quais, por isso mesmo, se regem pela legislação privada. 
Acrescenta-se que esse avanço da Constituiçāo de 1988 é uma conquista da racionalidade pública, de vez que trata de afirmar a absoluta necessidade de que esses serviços sejam prestados com eficiência econômica, não pesando sobre os cofres do Estado, como seria, então, aceitável, no já ultrapassado Wellfare State Keynesiano, e, hoje, um claro indicativo de desgoverno.

Assim sendo, não vejo como aplicar à hipótese regras e preceitos inerentes à administração financeira do Estado, tais como os que tratam de previsão orçamentária, empenho $e$ tramitaçāo burocrática, os quais, inclusive, são incompatíveis com a dinâmica empresarial, e, muito menos reconhecer, a uma entidade de direito privado, o privilège du préalable, apanágio intransferivel do Estado (vide conclusão 13)"

Não desautoriza tal conclusão, embora não a confirme, a lição de Lucia Valle Figueiredo (Direito dos licitantes, São Paulo, RT, 1985, p. 40) que interpretando norma da anterior Carta, semelhante ao atual art. 173, $\S 1^{\mathbb{Q}}$, sustentou que a regra é dirigida ao aplicador da lei, no sentido de que não sejam beneficiadas as empresas estatais em detrimento das empresas de particulares, esclarecendo, porém, o seguinte:

"O texto constitucional pretende uma igualdade de regime, quando esta igualdade possa garantir, exatamente, o nāo aniquilamento da iniciativa privada.

A regra, pois, é de aplicação voltada de imediato à proteção da atividade privada.

Demais disso, não são as empresas públicas e sociedades de economia mista antes comparáveis, em tudo e por tudo, às empresas particulares, haja visto que: a. submetem-se a controle pelos Tribunais de Contas; $b$. nāo podem falir; $c$. os atos de seus diretores são passiveis de mandado de segurança; $d$. a ação popular é exercitável como remédio jurídico, caso celebrem contratos lesivos aos seus patrimônios." 
Já Celso Antonio Bandeira de Mello, em parecer publicado na Revista de Direito Público n. 97, p. 30-36, faz a devida distinção entre empresa exploradora de atividade econômica destinada a intervir no domínio econômico, atuando em esfera constitucionalmente reservada à empresa privada por força do princípio da livre iniciativa (CF, art. 170) - e empresa prestadora de serviço público mera descentralização administrativa, por questão de conveniência na delegação e personalização (por lei) de um serviço que cabe ao Poder Público.

Diz o renomado mestre, in verbis:

"Com efeito, é preciso distinguir as sociedades de economia mista e empresas públicas em duas distintas espécies, a saber: prestadoras de serviços públicos e exploradoras de atividade econômica, pois o regime de uma e outra não é idêntico. Ambas, pelas razões já expostas, inobstante sejam constituidas sob forma de direito privado, sofrem o impacto de regras de direito público. As primeiras, entretanto, são alcançadas por estes preceitos com uma carga mais intensa do que ocorre com as segundas, o que é perfeitamente compreensivel.

Deveras, as prestadoras de serviço público desenvolvem atividade em tudo e por tudo equivalente aos misteres típicos do Estado e dos quais este é o senhor exclusivo. Operam, portanto, numa seara estatal por excelência, afeiçoadas aos seus cometimentos tradicionais e que demandará, bastas vezes, o recurso a meios publicísticos de atuação...

Já as exploradoras de atividade econômica protagonizam seu empenho em um campo que é, por definição, o terreno próprio dos particulares, das empresas privadas, e ao qual o Estado só por exceçāo pode acorrer na qualidade de personagem empreendedor; ainda assim, este papel lhe é facultado apenas quando houver sido acicatado por motivos de alta relevância". 
Ainda a respeito da matéria, manifestou-se o eminente jurista Adilson Abreu Dallari, em parecer publicado na Revista de Direito Público n. 94, fls. 94-108, in verbis:

"Em resumo, as entidades privadas criadas pelo Estado para o desempenho de serviços públicos, as pessoas jurídicas de direito privado criadas pelo próprio Poder Público para desenvolver atividade tipicamente pública, podem e devem ter um regime muito mais assemelhado aos das entidades públicas; podem ter, sim, indubitavelmente, um tratamento privilegiado, inclusive quanto aos aspectos tributários, porque näo concorrem com as empresas privadas, não concorrem com os particulares em sentido estrito.

A doutrina e a jurisprudência já haviam entendido estas distinções quando do advento da Constituiçāo Federal de 1988. Pode-se dizer que o constituinte de 1988 percebeu claramente a existência de dois tipos de empresas estatais, as que desenvolvem atividades econômicas e as que prestam serviços públicos, motivo pelo qual em uma série de dispositivos cuida de situações que são comuns a qualquer uma dessas espécies de empresa estatal, mas, cientes da distinçāo, quando quis se referir à empresa estatal exercente de atividade econômica em sentido estrito deixou expressamente consignada essa referência".

No mesmo parecer, destaca-se a posição de José Afonso da Silva, a fls. 104-105, abaixo transcrito:

"Tenha-se presente essas distinções para a compreensão da natureza e limites das empresas estatais; pois sob o ponto de vista de sua função diferenciam-se em dois tipos: as prestadoras ou exploradoras de serviços públicos (como a CESP, a CEMIG, a Companhia do Metrô, a Telebrás, a Rede Ferroviária, a VASP, etc.), e as exploradoras de atividade econômica (como a Petrobrás, a Vale do Rio 
Doce, o Banco do Brasil, a Embraer, a Cosipa, etc.). O regime jurídico dessas empresas é diferente. As primeiras entram no conceito de descentralizaçāo de serviços pela personalização da entidade prestadora. $O$ modo de gestão desses serviços públicos, entre outros, não só de competência da União, mas também dos Estados, Distrito Federal e Municípios, entra no regime da discricionariedade organizativa, ou seja, cabe à Administração escolher se o faz diretamente, ou por delegação a uma empresa estatal (pública ou de economia mista) ou por concessão, autorização ou permissão a uma empresa privada".

Com igual sentido, confira-se a lição de Toshio Mukai, em estudo denominado A Empresa pública na nova Constituição, publicado no Boletim Legislativo ADCOAS, n. 09, de 30 de março de 1989, p. 324:

"O Estado não tem outra missâo senão a de buscar a satisfação do interesse público.

Isto ele o faz precisamente ao executar os serviços públicos, mas, mesmo quando explore atividade econômica, ele só pode fazê-lo escudado também num critério de interesse público.

Entretanto, a noção de interesse público pode ser entendida como expressão do valor público que em si mesmas têm certas coisas, ou bem como expressão daquilo que interessa ao público.

Assim, podemos dizer que 'serviço público industrial ou comercial é aquele que o Estado, ao elegê-lo como tal, exerce-o diretamente ou por interpostas pessoas, e que, por atender a necessidade essencial ou quase essencial da coletividade, apresenta um interesse público objetivo em sua gestāo. E atividade econômica do Estado é aquela que ele resolve assumir, dentro de sua política econômica, observados os princípios constitucionais da Ordem Econômica, por julgar que tal.atividade consulta ao interesse 
público da mesma Ordem (interesse público subjetivo)'. (Cf. nossa ob. cit., p. 183).

E, como conseqüência, podemos ter, no Brasil, empresas públicas que exercem serviços públicos comerciais ou industriais, e empresas públicas que exploram atividades econômicas.

Dai termos traçado os regimes jurídicos de uma e outras (diferentes), as primeiras como substrato jurídico administrativo saliente, $e$ as segundas, como substrato jurídico de direito privado preponderante (Cf. nossa ob. cit., p. 185 e ss. e p. 237 e ss.)".

O próprio Decreto-lei n. 2.300/86 faz, no art. 86 e seu $\S 1$, a distinção em relação às estatais destinadas ao exercício de política industrial.

Filiamo-nos, data venia dos doutos mestres, à corrente que faz a distinção.

\section{Empresas estatais de Estados e Municípios.}

Viu-se, acima, que a competência para legislar sobre direito comercial é privativa da União $\mathrm{CF}$, art. 22 , I que, dispondo sobre o tema estabeleceu, no art. 5o, II do Decreto-lei n. 200/67, liberdade para as empresas públicas se constituírem sob "qualquer das formas admitidas em direito", enquanto que a sociedade de economia mista só pode assumir a forma de S.A., conforme dispõe o inciso III do mesmo dispositivo, o que vem reafirmado no art. 235 da Lei de Sóciedades Anônimas - Lei n. 6.404, de 15.12.76 que expressamente submete tais sociedades mistas aos seus preceitos.

Diante de tais disposições, construiu-se um entendimento de que seria vedado aos Estados e Municípios criar tais empresas por faltar-lhes competência para legislar sobre direito comercial.

Data venia, ousamos discordar, com apoio na lição sempre atualizada de Celso Antonio Bandeira de Mello, que, em sua clássica obra Prestação de Serviços Públicos, $2^{\mathrm{a}}$ ed., São Paulo, RT, 1987, p. 107-8, sustenta que "as normas especiais que os legislativos estaduais e municipais promulguem para a regência de suas sociedades não são normas de direito comercial, cuja edição lhes 
é vedada, mas normas de direito administrativo, expedidas no exercício de competência própria"

Destarte, se há empresas estatais de intervenção no domínio econômico e as de prestação de serviços públicos, estas últimas, como exercício da descentralização de uma função típica do Estado, podem ser criadas em decorrência da própria autonomia de organização e administração inerente à divisão especial do poder.

Aduzia, contudo, o nobre jurista, que não pode haver tais empresas estaduais e municipais exploradoras do domínio econômico por duplo motivo:

"a. porque Estados e Municípios, nāo podendo legislar sobre direito comercial, estariam sem título jurídico para a emissão das 'normas especiais', que seriam, ai sim, normas de direito mercantil (não de direito administrativo) porque reguladoras da atividade entregue, pela Constituição, à iniciativa privada e, bem por isso, disciplinável pelo direito privado; comercial, no caso;

b. porque a intervençāo no domínio econômico é privativa da Uniāo, tanto ao exercer função supletiva da iniciativa privada, na forma do artigo 170 da Lei Magna, quanto ao interferir com base no artigo 163 que domina toda a matéria e faculta, mediante lei federal, o monopólio de indústria ou atividade em nome da segurança nacional ou da organizaçāo de setor que não possa ser desenvolvido eficazmente em regime de competição e livre iniciativa".

Entendemos, data venia, que o segundo argumento não mais remanesce in totum, já que a Constituição de 1988 não repetiu a exigência da lei federal interventiva como o fez no art. 163 da Carta de 1967. Não obstante, as normas gerais de Direito Econômico, onde se situam as disposições legais de intervenção do Estado na economia, remanescem com a União $\mathrm{CF}$, art. 24, I e $\S 1^{\circ}$.

Cabe, pois, a criação de empresas estatais por Estados e Municípios, desde que destinadas à prestação de serviços públicos de suas 
competências e observadas as formas societárias previstas na legislação comercial federal.

\section{A privatização como correção dos abusos na descentralização.}

Uma das propostas tidas como "modernizantes" do Governo Collor foi a de redução do déficit público através da redução da máquina administrativa do Estado.

Foi, então, editada a Lei n. 8.031, de 12 de abril de 1990, instituindo o Programa Nacional de Desestatização, dotado de uma preocupação também de caráter filosófico, qual seja, o de que a atividade produtiva compete à iniciativa privada, cabendo ao Estado zelar para que seja mantido o bem-estar social. Trata-se de princípio que norteia o funcionamento do Estado brasileiro e vem estampado logo no artigo inaugural da Carta Magna (inciso IV). É a nova concepção de Estado, intermediária entre a filosofia liberal e a intervencionista o Estado Bem-Estar.

Cumpre, pois, que se faça a retirada do Estado de setores que ocupa sem amparo na Constituição. A presença estatal em setores que não se refiram a imperativos de segurança nacional, relevante interesse coletivo ou prestação de serviços públicos deve cessar ainda que o seu desempenho seja eficiente e rentável. Afinal, não é o lucro que está em jogo mas um limite constitucional traçado para a atuação interventiva estatal. $\mathrm{O}$ desrespeito a esses limites é a negação do próprio Estado de Direito.

Por outro lado, é inegável o aspecto pragmático desse processo, já que não se pode, com poucos recursos, ser eficiente em um variado número de áreas e atividades.

Sendo insuficientes esses recursos, torna-se indispensável que sejam eles destinados a funções típicas do Poder Público, como as já mencionadas - educação, saúde, saneamento e segurança, as quais se encontram em precaríssima situação.

Tão importante quanto redirecionar esses recursos é reduzir os gastos estatais com a manutenção de uma máquina administrativa gigantesca (e muitas vezes inútil), a fim de que as verbas disponíveis e as outras que ingressarem nos cofres públicos resultem num efetivo proveito em termos de 
eficiência. $O$ plano surgiu em meio a um pacote de medidas que visavam a extinguir órgãos públicos, demitir o excesso de pessoal, alienar bens inúteis ou onerosos à Administração a uma maior arrecadação, não apenas através da instituição de novos tributos, mas também numa maior fiscalização no pagamento daqueles já devidos. Uma farsa, que ainda não vingou, aguardando-se mais uma reforma constitucional.

Outra verdade que precisa ficar clara é que o processo de privatização até então não tinha sido implantado por falta de vontade política do Governo, muito embora os diplomas legais então vigentes não tratassem adequadamente da matéria.

A Lei n. 4.728/65, em seu art. 60, autorizava o Poder Executivo a alienar apenas as ações de sociedade de economia mista, ressalvando a necessidade de manutenção da maioria das ações com direito a voto nas empresas em que deva ser assegurado o controle estatal (sabendo-se que estas seriam apenas as prestadoras de serviço público ou que atendam a relevante interesse coletivo e à defesa nacional). Portanto, não abrangeu as empresas públicas.

A única forma de privatização sugerida era a venda de ações (pela própria natureza do diploma legal em que se insere o dispositivo).

O Decreto-lei n. 200/67, por sua vez, no art. 178 (com a redação dada pelo Decreto-lei n. 2.299/86) não se preocupava com a prestação de serviços públicos, relevante interesse coletivo e segurança nacional, ditando como critério autorizativo da privatização a ocorrência de prejuízo, a inatividade e $o$ atendimento satisfatório pela iniciativa privada.

Tinha, contudo, o mérito de abranger outros entes da Administração descentralizada (e não apenas as sociedades de economia mista).

A privatização não seria, segundo o dispositivo, a única forma de solução para as inconveniências dessas entidades, que poderiam retornar à Administração centralizada ou ser incorporadas a outras entidades. Poderia, assim, a critério do Executivo, permanecer presente o Poder Público nas atividades por ela representadas.

Em resumo, nenhum dos diplomas legais oferecia qualquer solução técnica e definitiva para o problema. 
A privatização:

- não pode abranger apenas as sociedades de economia mista, quando há empresas públicas, fundações e até autarquias desempenhando papéis que não mais competem ao Poder Público, segundo o princípio da livre iniciativa (quiçá jamais competiram!);

- não pode ter por motivação apenas o prejuízo, a paralisação ou o atendimento satisfatório, pela iniciativa privada, das atividades desenvolvidas pelas "estatais"; ao contrário, o objetivo é mais amplo, qual seja, o de fazer o Poder Público retornar aos limites constitucionalmente aceitos, independentemente dos fatores acima;

não pọe ser instrumento através do qual o Poder Público se demite do seu dever de prestar serviços públicos, atender aos relevantes interesses coletivos e zelar pela segurança nacional, haja ou não lucro nessas atividades;

não é atendida, apenas, através da simples venda de ações, podendo ocorrer através do aumento de capital, alienação ou locação de bens, etc.;

deve ser precedida de um saneamento das empresas envolvidas, de forma a tornar-se atrativa ao setor privado.

Enfim, a privatização, além de um imperativo constitucional, é também um dever de eficiência técnico-administrativa, passando-se para quem pode fazer melhor aquilo que o Estado não mais tem condições de tocar. $O$ conceito de terciarização não envolve apenas a iniciativa privada. 